\title{
THE GENEALOGY OF SOCIAL HISTORY OF ISLAMIC EDUCATION POLITICS IN INDONESIA
}

\author{
Choirul Mahfud \\ Choirul.Mahfud@its.ac.id \\ Institut Teknologi Sepuluh Nopember (ITS) Surabaya, Jawa Timur Indonesia
}

\begin{abstract}
Studying on the politics of Islamic education in Indonesia cannot be separated from historical aspects. This study discusses why and how the history of Islamic education cannot be separated from the birth, growth and development of Islamic education in a country. In the Indonesian context, the political history of Islamic education cannot be separated from the dynamics of Islamic education and power from time to time, starting from the pre-independence period to the present. This article uses qualitative research methods that emphasize the study of documents or texts. That is, the study of the text in this study focuses more on the analysis or interpretation of written material based on the context. The results of this study indicate that the relationship between history and politics of Islamic education in Indonesia is very close and strong relationship. Azyumardi Azra sees the historical aspect as very dominant in constructing the political reality of Islamic education in Indonesia from time to time. In this context, Michel Foucault gives attention to the genealogical aspects in history which focus on the origin and form of the history of knowledge which in certain contexts cannot be separated from power.
\end{abstract}

Keywords: Social History, Islamic Education Politics, and Educational Reform

\begin{abstract}
Abstrak
Studi politik pendidikan Islam di Indonesia tidak dapat dilepaskan dari aspek sejarah. Penelitian ini membicarakan mengapa dan bagaimana sejarah pendidikan Islam tidak bisa dilepaskan dari lahir, tumbuh dan berkembangnya pendidikan Islam dalam suatu negara. Dalam konteks Indonesia, sejarah politik pendidikan Islam tidak bisa dilepaskan dari dinamika pendidikan Islam dan politik kekuasaan dari waktu ke waktu, mulai dari masa pra-kemerdekaaan hingga saat ini. Artikel ini menggunakan metode Penelitian kualitatif yang menekankan pada studi dokumen atau teks. Maksudnya, studi teks dalam kajian ini lebih menitik beratkan pada analisis atau interpretasi bahan tertulis berdasarkan konteksnya. Hasil penelitian ini menunjukkan bahwa hubungan antara sejarah dan politik pendidikan Islam di Indonesia sangat dekat dan kuat. Azyumardi Azra melihat aspek sejarah sangat dominan dalam mengkonstruksi realitas politik pendidikan Islam di Indonesia dari waktu ke waktu. Dalam konteks inilah, Michel Foucault memberikan perhatian tentang aspek genealogi dalam sejarah yang memfokuskan asal usul sekaligus pembentuk sejarah pengetahuan yang dalam konteks tertentu tidak lepas dari kekuasaan.
\end{abstract}

Kata kunci: Sejarah Sosial, Politik Pendidikan Islam, dan Reformasi Pendidikan 


\section{INTRODUCTION}

Many historical accounts explain that growth and development of Islamic education in this country cannot be separated from the history of the entry and development of Islam in the archipelago which intersects the situation of social, cultural and political conditions at that time. Islam entered Indonesia, at least from various information, there were four theories, namely; Arabic, Indian, Persian and Chinese. Each theory asserts that Islam in Indonesia is influenced by several scholars who came to the archipelago from several countries, through trade, diplomacy, marriage and so on. For example, Sumanto al-Qurtuby in the book "Chinese-Islamic-Javanese Flow: Unloading History of the Role of Chinese in the Spread of Islamic Religion in the Archipelago", suggests that the Islamization of the archipelago cannot be separated from the role of Chinese named Cheng Ho. The historicity and relevance of Cheng Ho's expeditionary mission in the homeland feels increasingly meaningful, at least for the relationship of Islam, Indonesia and China, now and tomorrow. Moreover, to this day there is no clear "status" of the role of Chinese Muslims in the process of entering Islam to the archipelago. In fact, Cheng Ho had spread Islam in the archipelago long before the Walisongo broadcast Islam on Java.

In this context, Cheng Ho's presence indeed gave rise to a new discourse in the study of contemporary Islam in Indonesia. In fact, this topic has provoked academics and historians to rethink the issues of Islamization in Java. The reason is, the presence of Islam in Indonesia, generally associated with the three previous major theories, namely the Arab, Indian and Persian theories. Later, the three major theories above drew criticism. Besides Sumanto al-Qurtuby, academics and historians at the international seminar entitled Cheng Ho, Wali Songo and Chinese Muslims held by the Muhammad Cheng Ho Indonesia Foundation in Surabaya a few years ago, also considered the history of Islamization in Indonesia as inseparable from Chinese theory. This theory states that Islam spread to the archipelago not only through the Middle East/ Arabic, Persia and India, but also the influence of China which was marked by Cheng Ho's expedition to the homeland. Some lessons that can be taken from Cheng Ho's expedition include: the achievements of his success in building social solidarity and global economic-political stability and the Islamization of the archipelago through acculturation of Chinese-Islam, without violence. 
The achievement of social solidarity, as told in the film Cheng Ho, played by Yusril Ihza Mahendra and Syaifullah Yusuf, has shown how Cheng Ho was leading the voyage with a number of crew members from various ethnic and religious backgrounds. However, he still respects the beliefs and beliefs of each individual and safeguards the surrounding environment. In his capacity as a trader, ambassador of knowledge and culture to many countries representing China at that time, Admiral Cheng Ho was also known as a businessman who helped maintain economic stability as well as a reliable political diplomat that impressed many parties.

The question is, why does history (Islam) hardly mention the role of Chinese Muslims from China (Cheng Ho) in the Islamization of this archipelago? Perhaps it is true that history belongs to the rulers. At that time, the history of the entry of Islam could not be separated from the situation of "domination" of the socio-political history of the Majapahit kingdom. In the pages of history, the beginning of Cheng Ho's arrival in Indonesia had experienced a "misunderstanding" that sparked a war with the Majapahit army. However, whether they lost or relented, they finally settled in the Majapahit region and helped support it through knowledge and trade transfers. Cheng Ho's expedition to the archipelago actually carried many missions and agendas. In addition to introducing Chinese culture and business, Cheng Ho also preached a syariah religion (Islam) with a multicultural approach.

Multiculturalism as a social fact seems to be well aware of Cheng Ho in knitting the vision and mission on expeditions to various countries, including in this archipelago. As we know that Cheng Ho himself was actually the name bestowed by Emperor Yung Lo, the 3rd emperor of the Ming Dynasty who ruled around 1403-1424. Cheng Ho's real name is Ma Ho. He is from the clan Ma, born to a poor ethnic Hui family in Yunnan. He did an expedition to many countries because he was trusted by the Emperor at that time. Interestingly, but still a matter of historical debate, the roots of Cheng Ho's descent have led to the Prophet Muhammad.

According to Nadalsyah, he belonged to the 37th descendant of the Prophet Muhammad. Not only that, Benny G. Setiono also revealed that he was said to be one of nine Wali Songo. The statement above was also reaffirmed by Gus Dur (KH Abdurrahman Wahid) at Cheng Ho's international seminar in Surabaya. In fact, Gus Dur said "I am of 
Chinese ethnic origin". It was also acknowledged by his daughter who told that Gus Dur was indeed a descendant of the Tan clan. In this context, exploring history can depart from the explanation of Ibn Khaldun in the book "Muqaddimah" which describes the essence of history, namely talking about human civilization, including civilization in education.

\section{RESEARCH METHODS}

This section describes how the reported research is carried out with qualitative research. This section describes the approaches and methods used in research, as is usual in qualitative research. In particular, the qualitative research emphasized in this paper is the study of documents or texts. It means that this text study focuses more on the analysis or interpretation of written material based on the context. Materials can be published notes, text books, newspapers, magazines, letters, films, diaries, texts, articles, and the like (Moleong, 2010). This type of research can also be used to explore someone's thoughts contained in published books or texts.

\section{RESULTS OF THE STUDY AND DISCUSSION}

Azyumardi Azra download stated that civilization is very dependent on how the education system is organized. Azyumardi emphasized that Islamic civilization would be upright if education was good and correctly responded to future sociocultural changes (Azra, 2012). Azyumardi is also optimistic about Islamic education in Indonesia because he has been able to adapt to the demands of modernity. According to him, it has been realized that Indonesian Muslims display a more moderate, more multicultural and very open characteristic of Islam. This recognition was given not only by domestic intellectuals but also by foreign observers. Islam here has been tested for centuries in its interaction with tradition, soul and all its historical movements (Ali, 2013; Mahfud, 2018).

During his struggle with the culture of the archipelago, Islam was very accommodating and able to enrich the eternal and universal ideas of our nation. Therefore, the color of Islam here is better able to absorb change, progress and adaptability. Of course, this open character does not appear suddenly. There is a group of elites, religious institutions and wisdom that play a role. There is a very dynamic long time span in giving responses. They are educational institutions (madrasas, boarding schools, and ulama). In 
contemporary Indonesian society, these roles are more dynamic, especially, because of the outbreak of a new generation of Islam entering Islamic colleges such as the IAIN, the State Islamic College (STAIN) and the State Islamic University (UIN).

In historical records, a map of the journey of Islamic education in Indonesia began at the beginning of the twentieth century until today is a long journey. Drastic developments took place during the Old Order and continued to develop during the New Order to reform. In the Old Order era, after Indonesia's independence, religious education could be said to have begun to receive serious attention from the government, both in public and private schools. The effort began with providing assistance as recommended by the Central National Committee of Workers (BPKNP) dated December 27, 1945, stated:

"Madrasas and pesantren which are essentially a source of education and intelligence for ordinary people who have been deeply entrenched and deeply rooted in Indonesian society in general should get attention and real assistance in the form of guidance and material assistance from the government".

Religious education is specifically regulated in Law No. 4 of 1950 in Chapter XII Article 20, namely: In religious schools, religious studies are held, parents determine whether or not their children will attend the lesson. The way in which religious education in state schools is administered is regulated by the Minister of Education, Teaching and Culture, together with the Minister of Religion.

The development of Islamic education during the Old Order was very closely related to the role of the Ministry of Religion which was officially established on January 3, 1946. The Ministry of Religion as an institution at that time, intensively championed the politics of Islamic education in Indonesia. Islamic education at that time was handled by a special section that dealt with the issue of religious education, namely the Religious Education Section. The tasks of the section are in accordance with one of the Islamic education in Indonesia notes compiled by the Department of Religion's Education Section on September 1, 1956, namely: 1) providing religious instruction in state and private schools, 2) providing general knowledge in madrasas, and 3) hold Religious Teacher Education and State Islamic Judge Education. Based on this information, there are 2 important things related to Islamic education in the old order, namely the development and development of madrasas and Islamic education in public schools. 
In the New Order era, the development of Islamic education entered a new phase, starting with the policy in article 4 of the TAP MPRS No. XXVII / MPRS / 1966 which contains policies on the content of education. To achieve the basis and purpose of education, the contents of education are: 1. Enhancing mental, moral, ethical and strengthening religious beliefs. 2. Enhancing intelligence and skills. 3. Fostering and developing a strong and healthy physique.

After the New Order, the government continued to pay considerable attention to the implementation of religious education. With the issuance of Law No. 20 of 2003, the position of Islamic education as one of the elements of the creation of national education goals, in general, is reinforced. As in Article 3, National Education aims to develop the potential of students to become human believers and devotees to God Almighty, have noble character, are healthy, knowledgeable, capable, creative, independent, and become democratic and responsible citizens.

Then, in Article 12 paragraph 1a, each student in each education unit has the right to receive religious education in accordance with the religion. In this case, the implementation of Islamic education has a great opportunity to develop its institutional capacity by improving the quality of Islamic education systems and services in order to succeed the national education goals.

\section{Rethinking Epistemology of the Social History of Islamic Education}

The conception of Islamic education can be understood from several perspectives. Azyumardi Azra in his book "Islamic Education, Tradition and Modernization towards the New Millennium", sees from the point of view of processes rather than results. Obviously, Azyumardi Azra defines Islamic education as an educational process that emphasizes guidance, not a teaching which means authoritative education executors who tend to transfer knowledge. According to Azra, Islamic education is also a transformation of values and the formation of personality with all aspects covered.

Mujamil Qomar in the book "Epistemology of Islamic Education: From the Rational Method to the Critical Method", looking from an epistemological perspective. According to him, epistemology is the key to answering fundamental problems in Islamic education. Because so far the science of Islamic education has not been based on a solid epistemology of Islamic education. If education determines the progress and glory of 
civilization, according to him, then Islamic education must be strengthened with a strong foundation. This strong foundation can exist if it is based on established epistemology (Qomar, 2005).

In particular, the discussion of the term epistemology method of Islamic education is distinguished by the method of Islamic education. If this method of Islamic education intends to discuss the methods used to deliver Islamic education material, the epistemology method of Islamic education is intended as methods used in exploring, compiling and developing Islamic education. In other words, are the methods used in building the science of Islamic education. According to him, there are 5 epistemological methods of Islamic education, namely: rational methods, Intuitive methods, dialogical methods, comparative methods, methods of criticism.

According to Qomar, the epistemology of Islamic education includes discussions relating to the ins and outs of the knowledge of Islamic education starting from the nature of Islamic education, the origin of Islamic education, sources, methods of building and developing Islamic education, elements of Islamic education, goals (objects), to various policy of understanding Islamic education.

The conception of Islamic education can also be understood from a linguistic and semantic perspective. According to Muhammad Naquib Al-Attas, semantically, the term Islamic education is usually translated from Arabic with several vocabularies, including tarbiyah, tadris, ta'dib, tahdib, and ta'lim. From the five vocabularies words the most popular and the most widely used is the term tarbiyah. Although, in its conceptual review structure, ta'dib is considered more representative and includes all elements, such as' ilm, ta'lim, tadris and tarbiyah. The thought of al-Attas who tended to choose the term ta'dib in the conception of Islamic education was not denied. Ridlwan Nasir actually prefers the term ta'lim, because it is considered more general for the term teaching in the tradition of Islamic boarding school education in Indonesia.

In the book "Reconstruction of Islamic Education", Muhaimin provides a perspective on the definition of Islamic education that can be understood from two meanings; first, Islamic education is an educational activity held or established with the desire and intention to embody Islamic teachings and values (Muhaimin, 2012) . In practice, Islamic education is realized such as Islamic boarding schools, diniyah madrasas, 
PAI in schools, and the like. Second, Islamic education can be understood as an educational system that is developed from and encouraged or inspired by Islamic teachings and values. In this context, Islamic education includes educators and stakeholders of Islamic education.

Basically, A Naguib al-Attas, as quoted by Nur Uhbiyati in his book "Islamic Education", also provides an explanation of the definition of Islamic education, namely the effort carried out by educators to students for the introduction and recognition of the correct places of everything in the order creation so that it leads to the recognition and recognition of God's place right in the order and form of personality. Hasan Langgulung, as quoted by Nur Uhbiyati, gave the characteristics and characteristics of the functions of Islamic education, namely: to prepare the young generation for their future; move knowledge; then move the values of wholeness and unity in society.

While Abdurrahman Nahlawi quoted by Nur Uhbiyati explained that Islamic education is a personal and community arrangement to embrace Islam logically and in accordance with its entire life both individually and in groups. Ahmad Tafsir as quoted by Imam Machali in his article "Islamic Education Policy From Time to Time", describes the definition of Islamic education as guidance given by someone so that he develops optimally in accordance with Islamic teachings. Al-Syaibaniy as quoted by Machali argues that Islamic education is a process of changing the behavior of individual students in their personal lives, society and the natural environment. The process is carried out by means of education and teaching as a basic activity and profession among the many professions in society. In fact, borrowing the term Amin Abdullah, the conception and practice of Islamic education should rest on the integrative-interconnect paradigm, not merely on the aspects of scientific and institutional dichotomy. The interconnection paradigm, in axiology, wants to offer a more open view of the human world, capable of dialogue until cooperation, transparency, public accountability, and forward vision. Ontologically, relations between various scientific disciplines become increasingly open and fluid (Jackson, 2004; Jalaluddin, 2003).

From the explanation of Islamic education experts above, it can be understood that the meaning of Islamic education is a conscious and planned effort in teaching the values of Islamic education by educators to students in order to educate life and shape 
human character according to the teachings of Islam. In that context, the task and function of Islamic education is actually not just a process of transferring knowledge (transfer of knowledge), but also can be interpreted as a process of transferring values. Therefore, the basics of relevant Islamic education are needed to support the implementation of the objectives of Islamic education. The fundamentals of Islamic education, namely: the Qur'an, Hadith/ as-Sunnah, and educational legislation that applies in Indonesia, such as the 1945 Constitution, Pancasila, National Education System Law and other related regulations.

In a broader context, the conception of Islamic education is carried out throughout life. The Prophet Muhammad in several hadiths even advocated the importance of lifelong learning from birth to death. This conception is in line with the idea of 4 Universal Education Pillars that UNESCO Formulated, namely: learning to know, learning to do, learning to live together and learning to be.

According to Wina Sanjaya in the book "Learning Strategies Oriented with Standard Processes in Education", it was explained at length what the four universal education means. First, learning to know. With the learning process, students are not only aware of what must be learned, but also have awareness and ability to learn how to learn (Shihab, 1999; Turmudi, 2004). With that ability allows the learning process will not stop or be limited to school, but allows students to continuously learn and learn. This is the essence of lifelong learning. If this is owned by students, then the learning society as one of the demands of the information society will be formed. Therefore, in the context of learning to know it also means learning to think, because each individual will continue to learn when the ability and willingness to think in them grows.

Second, learning to do. In this stage, learning to do also means the learning process is oriented to learning by experience (Sada, 2015; Mahfud, 2017). Third, learning to be contains the notion that learning is forming human beings who "become themselves". In this sense, it also implies self-awareness as a being who has a responsibility as a caliph and is aware of all his shortcomings and weaknesses. Fourth, learning to live together is learning to work together. In this context, it also includes the formation of democratic societies that understand and are aware of the existence of any changes in views between individuals (Langgulung, 1985; Mahfud, 2019). 
From the explanation of the four pillars of the UNESCO version of education above, it appears that there is conformity with the conception of Islamic education in Indonesia, although there is also one more pillar that is important and relevant to the conception of education in Indonesia. As disclosed by Diana Nomida Musnir in the article "Five Pillars of Learning to Realize the National Education Goals" that one more pillar is the fifth pillar of learning to believe and to convince the Almighty God (Learning to believe and devote to God the Almighty).

The proposal for the addition of the fifth pillar is certainly very reasonable because the Indonesian people have also affirmed in the first principle of Pancasila, namely the Almighty Godhead. Furthermore, Muh. Nuh as the Minister of Education and Culture at that time once revealed the government's commitment to the right to lifelong education for anyone, anywhere and anytime. The government commitment is now better known as the five pillars of Indonesian education which includes the availability pillars, affordability, quality pillars, and assurance pillars and equity. What is meant by some of these pillars, Fasli Jalal quoted the opinion of Muh. Nuh once stated how to make the availability of educational services available. If there are Indonesian children who want to go to school, don't let the existing capacity not accommodate them enough. So the education path must be there (Latif, 2005; Mahfud, 2016).

According to him, that alone is not enough, so after observing the availability, there must be the ability of students or parents to get access to those already available. Affordability, affordability at available capacity. Then, he said, even that was not enough, so the quality of the service, which was affordable and available, had to be qualified because if it wasn't quality, it would reduce the well-being of our students. In addition, he said, there must also be equality: between village and city equality, which requires special and normal attention, gender equality, equality in socio-economy. Also, according to him, how to guarantee or guarantee that the above 4 things were carried out in operation. The same was expressed by the Head of the Mathematics PPPPTK Center, Herry Sukarman, as quoted by Irsyakhafid in his website that the five pillars are: First, Pillar of Availability, which is related to the availability of adequate education services in accordance with standards, both in curriculum, resources, methods, strategy, and others. Second, the pillar of affordability. This pillar focuses on the principle of fulfilling the right to obtain 
education for all citizens without exception. To support this affordability, it needs to be supported by the use of various media and technologies (Nata, 1997; Ramayulis, 2008; Mahfud, 2017).

Third, the Quality Pillar. Improving the quality of education must now make the main concern, not only of outputs and outcomes but also concerning the education inputs and processes. Fourth, the pillar of education quality assurance. Guaranteed quality of education must be done more with various studies and evaluations about the factors that influence the improvement of education quality. The fifth is equality pillar. Education must reach all levels of society with no distinction. Indonesia is a large country with a variety of diversity, education must be able to serve all its citizens with equal and indifferent diversity.

\section{CONCLUSIONS AND SUGGESTIONS}

From the description above, it can be understood that the socio-political history of Islamic education in Indonesia has strong roots in the traditions of society and it is in line with the commitment of the Indonesian government in efforts to contribute to the intellectual life of society, the state, the nation, and the world. The socio-political history of Islamic education in a country is very important to note because it will determine the direction and dynamics of a nation's civilization through the implementation of a good education for all its citizens. In a broader perspective, the political history of Islamic education includes discussion of maps of Islamic education travel in political situations and conditions in a certain period of time that is influenced by the political aspects of power interest.

\section{BIBLIOGRAPHY}

Ali, Mohammad Daud. (2013). Pendidikan Agama Islam. Jakarta: PT Raja Grafindo Persada.

Azra, Azyumardi. (2002). Historiografi Islam Kontemporer: Wacana, Aktualitas dan Aktor Sejarah, Jakarta: Gramedia Pustaka Utama.

Held, David. (2004). Demokrasi dan Tantangan Global, Yogyakarta: Pustaka Pelajar.

Husni Thoyar. (2004). Pendidikan Agama Islam. Jakarta: Pusat Kurikulum dan Pembukuan.

Jackson, Robert. (2004). Rethinking Religious Education and Plurality: issues in diversity and pedagogy, New York: Routledge Falmer.

Jalaluddin. (2003). Teologi Pendidikan. Jakarta: PT Raja Grafindo Persada. 
Langgulung, Hasan. (1985). Pendidikan dan Peradaban Islam. Jakarta: Pustaka Al-Husna. Latif, Yudi. (2005). Intelegensia Muslim dan Kuasa, Bandung: Mizan.

Mahfud, Choirul. (2016). Politik Pendidikan Islam di Indonesia. Yogyakarta: Pustaka Pelajar.

Mahfud, Choirul. Understanding Education of Authoritative Islamic Law Perspective Khaled Abou el Fadl, MODELING: Jurnal Program Studi PGMI 6, no. 1 (March 13, 2019): 1-12.

, (2018). Chinese Muslim Community Development in Contemporary Indonesia: Experiences of PITI in East Java, Studia Islamika 25 (3).

Mahfud, Choirul, Muhibbin, Z, (2017), Materi PAI Berbasis Technopreneurship di ITS Surabaya, MODELING: Jurnal Program Studi PGMI 4 (2), 126-138

Mahfud, Choirul, Prasetyawati, et.al (2018) Religious Radicalism, Global Terrorism and Islamic Challenges in Contemporary Indonesia, Jurnal Sosial Humaniora 11 (1), 8-18

Mahfud, Farras Jauhari, (2018), Sekolahku Inspirasiku, Yogyakarta: Samudra Biru.

Moleong, Lexy J, (2010), Metode Penelitian Kualitatif, Bandung: PT. Remaja Rosadakarya.

Nata, Abbudin. (1997). Filsafat Pendidikan Islam. Ciputat: Logos Wacana Ilmu.

Purwanto, Edi dan Suyadi. (2004). Pendidikan Agama Islam. Surakarta: Widya Duta.

Ramayulis. (2008). Ilmu Pendidikan Islam. Jakarta: Kalam Mulia.

Sada, Heru Juabdin, (2015), Pendidik dalam Perspektif Al-Qur'an, Al-Tadzkiyyah: Jurnal Pendidikan Islam, Vol 6, No 1

Shariati, Ali. (1996). Tugas Cendekiawan Muslim. Jakarta: PT. Raja Grafindo Persada.

Shihab, Alwi, (1999). Islam Inklusif, Bandung: Mizan.

Turmudi, Endang. (2004). Perselingkuhan Kiai dan Kekuasaan, Yogyakarta: LKIS. 